\title{
A RESPEITO DA SOCIEDADE DO ESPETÁCULO E A TAREFA DA EDUCAÇÃO
}

\author{
ABOUT THE SOCIETY OF SPECTACLE AND THE TASK OF THE EDUCATION \\ ACERCA DE LA SOCIEDAD DEL ESPECTÁCULO Y LA TAREA DE LA EDUCACIÓN
}

Resumo: Guy Debord, na obra A Sociedade do Espetáculo (1997), afirma que toda a vida das sociedades nas quais reinam as modernas condições de produção se apresenta como uma imensa acumulação de espetáculos. O artigo, de bases teóricas e de caráter bibliográfico, busca compreender o conceito de Sociedade do Espetáculo, sua atualidade e implicações e, a partir da perspectiva Freireana $(1977,2017)$, refletir sobre a responsabilidade da educação em meio a este diagnóstico revelado por Debord no sentido de promover uma cidadania permanentemente revisitada, infindavelmente revisada e criticamente refletida. A educação não pode se furtar à tarefa de propor uma reflexão crítica sobre o cotidiano como forma de revelar e combater as artimanhas desse tipo de sociedade a fim de que a vida não caia numa artificialidade irrecuperável devido à nossa apatia em relação à lógica da economia hegemônica, rígida, dogmática e autoritária.

Palavras-chave: Sociedade do Espetáculo. Guy Debord. Educação. Freire.

Abstract: Guy Debord, in The Society of the Spectacle (1997), affirms that the whole life of the societies in which the modern conditions of production reign is presented as an immense accumulation of spectacles. The article has theoretical and bibliographic character and seeks to understand the concept of the Society of the Spectacle, its actuality and implications, from the Freire perspective (1977, 2017), thinks over the responsibility of the education in the midst of this demonstrated by Debord, in order to promote the citizenship permanently revisited, endlessly revised, and critically analyzed. The education cannot evade its responsibility of proposing a critical reflection on daily life, as a way of revealing and combating the tricks of this kind of society, with the proposal that life does not fall into na unrecoverable artificiality because of our apathy towards the logic of the hegemonic, rigid, dogmatic and authoritarian economy.

Keywords: Spectacle Society. Guy Debord. Education. Freire.

Resumen: Guy Debord, en The Society of the Show (1997), afirma que toda la vida de las sociedades en las cuales reinan las condiciones modernas de producción se presenta como una inmensa acumulación de espectáculos. El artículo, basado en el carácter teórico y bibliográfico, busca comprender el concepto de Sociedad del Espectáculo, su actualidad y implicaciones y, desde la perspectiva freireana $(1977,2017)$, reflexionar sobre la responsabilidad de la educación en medio de este diagnóstico revelado por Debord que promueve una ciudadanía permanentemente revisitada, revisada sin cesar y reflejada críticamente. La educación no puede eludir la tarea de proponer una reflexión crítica sobre la vida cotidiana como una forma de revelar y contrarrestar los trucos de este tipo de sociedad para que la vida no caiga en una artificialidad irrecuperable debido a nuestra apatía con respecto a la lógica de la economía hegemónica, rígida, dogmática y autoritaria.

Palabras-clave: Sociedad del Espectáculo. Guy Debord. Educación. Freire. 


\section{Introdução}

Guy Debord, na abertura de sua obra La Societè Du Spectacle (A Sociedade do Espetáculo) começa parafraseando Feuerbach: "E sem dúvida o nosso tempo... prefere a imagem à coisa, a cópia ao original, a representação à realidade, a aparência ao ser [...]" (DEBORD, 1997, p. 13). $\mathrm{O}$ autor francês, na obra, discute a noção de Sociedade do Espetáculo, que caracteriza, segundo ele, uma sociedade em que não mais se vive diretamente a vida natural, mas sim uma representação da vida cotidiana. Para Debord (1931 - 1994), "toda a vida das sociedades nas quais reinam as modernas condições de produção se apresenta como uma imensa acumulação de espetáculos" (DEBORD, 1997, p. 13). Primeira, das 221 afirmações que compõem o livro, essa tese indica que o Espetáculo é a característica principal das sociedades nas quais a vida real é pobre e fragmentada e os indivíduos são obrigados a contemplar e a consumir passivamente as imagens de tudo o que lhes falta em sua existência real. E é sobre essa tese que Debord, um pensador situacionista francês, cineasta e ativista, pós-marxista, se debruça a discutir a fim de compreender este elemento como determinante da nova ordem social existente no mundo.

Este artigo, de bases teóricas e de caráter bibliográfico busca, num primeiro momento, compreender o conceito de Sociedade do Espetáculo, sua atualidade e implicações e, a partir da perspectiva Freireana $(1977,2017)$, na segunda parte, refletir sobre a responsabilidade da educação em meio a este diagnóstico revelado por Debord no sentido de promover uma cidadania permanentemente revisitada, infindavelmente revisada e criticamente refletida.

Para fazer frente às implicações sócio-pedagógicas da Sociedade do Espetáculo, diagnosticada por Debord (1997), em que reinam as modernas condições de produção econômicas e onde a vida se apresenta como uma imensa acumulação de espetáculos, nos apoiamos em Freire que sugere a adoção de processos educativos-comunicativos que estejam alicerçados na colaboração e no diálogo permanente com vistas a transformação social e a formação de um sujeito autônomo.

\section{Guy Debord e o conceito de sociedade do espetáculo}

Na obra A Sociedade do Espetáculo, escrita em 1967, Debord, ampliando as ideias da Escola de Frankfurt ${ }^{1}$, apresenta uma crítica ao modus operandi da sociedade capitalista em que o espetáculo que inverte o real é produzido de forma que a realidade vivida acaba materialmente invadida
* Doutor em Educação pela Universidade de Passo Fundo (UPF). Técnico em Assuntos Educacionais na Universidade Federal de Santa Maria -Campus Frederico Westphalen.

E-mail: ricardo.cocco@ufsm.br
1 A Escola de Frankfurt consistia em um grupo de intelectuais que, a partir da década de 1920 , produziu um pensamento conhecido como Teoria Crítica. Dedicaram-se ao estudo dos problemas tradicionais do movimento operário, unindo trabalho empírico e análise teórica. Os autores ligados à Escola de Frankfurt não se pretendiam ser comentadores ou intérpretes do pensamento de Marx, mas tinham como proposta buscar inspiração no marxismo para uma análise da sociedade contemporânea. 
pela contemplação do espetáculo, "[..] é, simultaneamente, o resultado e o projeto do modo de produção existente" (DEBORD, 1997, p. 15). Essa Sociedade do Espetáculo caracteriza-se como uma endemia social, na qual os indivíduos criam uma situação de alienação em relação à sua própria vida real, creditando verdade a tudo aquilo que as imagens apresentam. Para Mattos (2005, n.p.) nesse modelo de sociedade: "[...] os homens os produzem e adoram, atribuindo poderes sobrenaturais a objetos materiais". Os produtos a que se refere estão diretamente ligados às necessidades que o sistema cria nas pessoas por meio da orientação de seus desejos, e que tornam atraentes os produtos oferecidos pelo mercado. Essa é a forma de representação da realidade mais comum na modernidade e, por isso, a mais poderosa.

Percebe-se então que, no Espetáculo, o uso de representações, se faz presente em todo o viver. Para Debord, esta situação caracteriza que: “[...] o espetáculo não é um conjunto de imagens, mas uma relação social entre pessoas, mediada por imagens [...]" (DEBORD, 1997, p. 14). Ele usa o termo "Sociedade do Espetáculo" a fim de compreender a forma de organização da estrutura social e as manifestações que possui na sociedade atual, tanto na política como na economia, na cultura e na educação. Dessa forma, há um distanciamento da realidade, pois a sociedade espetacular caracteriza-se não pela simples contemplação de representações da realidade, mas também pela própria reprodução do espetáculo na sociedade. $\mathrm{O}$ espetáculo é o meio pelo qual o sistema capitalista, a economia de mercado vigente, garantem a sua manutenção. "O espetáculo submete para si os homens vivos. [...] Ele não é nada mais do que a economia desenvolvendo-se para si própria.” (DEBORD, 1997, p. 16). É a produção e o consumo alienado dando uma falsa experiência da realidade.

Os meios de comunicação de massa, nesse sentido, em certa medida, são tomados como instrumentos para propagação e reprodução deste espetáculo sem limites. Debord afirma que os meios de comunicação de massa representam a manifestação superficial, nem por isso menos esmagadora, do espetáculo "[...] que aparentemente invade a sociedade como simples instrumentação, estão longe da neutralidade, são a instrumentação mais conveniente de seu automovimento total” (DEBORD, 1997, p. 24).

Tudo o que se vive, diz Debord, nada mais é do que representação de uma vida real, mas de forma ilusória. O Espetáculo 
consumo, de tudo àquilo que falta à vida real do homem comum. Celebridades, atores, políticos, personalidades, gurus, mensagens publicitárias - tudo transmite uma sensação permanente de aventura, felicidade, grandiosidade e ousadia. O Espetáculo é a aparência que confere integridade e sentido a uma sociedade esfacelada e dividida. É a forma mais elaborada de uma sociedade que desenvolveu ao extremo o 'fetiche da mercadoria' (felicidade identificada ao consumo). Onde os Meios de Comunicação de Massa são apenas a manifestação superficial mais esmagadora deste fenômeno da Sociedade do Espetáculo, que faz o indivíduo um ser infeliz, sempre insatisfeito, anônimo e solitário em meio à massa de consumidores (ARBAX JUNIOR, 2001, p. 69).

A realidade torna-se espetáculo, a partir de um aparato tecnológico, de imagens e representações e, estas, por sua vez, acabam constituindo a realidade. As relações entre os homens já não são mais mediadas pelas coisas, mas diretamente pelas imagens. Nesse tipo de construção social, não somente as relações sociais, mas econômicas, culturais, religiosas, afetivas, educacionais, etc., são estabelecidas sob tal égide.

Debord considera o espetáculo como um agente de manipulação social e conformismo político - "uma permanente Guerra do Ópio" (DEBORD, 1997, p. 34) - que visa entorpecer os atores sociais, turvando-lhes a consciência acerca da natureza dos fatos, dos efeitos do poder e da opressão capitalista. Para o autor, nesta perspectiva, "[...] tudo o que antes era vivido se esvai na fumaça da representação. Vivemos como se estivéssemos num não-mundo, ou um universo de ilusões" (DEBORD, 1997, p. 13). Na Sociedade do Espetáculo o operário, o estudante, a dona de casa, enfim, todos de uma forma geral, passam a ser adulados por imperativos culturais e pirotécnicos e tendem a se converterem em meros consumidores. A vida se converte em show, o "show da vida". Identificamo-nos com o(a) ator(atriz) da novela (ele/a) vive a nossa vida ou aquela que queríamos viver. Ficamos acomodados com o discurso cheio de oratória do político. Somos anestesiados com as tragédias humanas tornadas espetáculos ante nossos olhos. Esquecemos da dura realidade do dia a dia que nos persegue ao apreciarmos o espetáculo de nosso "time do coração" ou do carnaval; e, por fim, consumimos produtos, ideias e comportamentos bem embalados, visto que hoje o "[...] empacotamento simbólico gera uma indústria da imagem e uma nova estética da mercadoria [...]” (FREIRE FILHO, 2003, p. 39). Desta forma, a própria embalagem 
não é mais pensada apenas como proteção contra os riscos do transporte, mas é um verdadeiro rosto a ser visto pelo comprador em potencial. Percebemos uma crise da experiência subjetiva e a proliferação de autômatos sem sujeito.

A discussão a que se propõe Debord aponta para uma perversão da vida moderna que prefere a imagem e a representação ao realismo concreto do cotidiano. Os homens, pela mediação das imagens e mensagens, principalmente proliferadas em uma velocidade inimaginável pelos meios de comunicação de massa, da cultura do consumo e da educação convencional abdicam da dura realidade dos acontecimentos da vida e passam a viver num mundo movido pelas aparências e pelo consumo permanente de fatos, notícias e ideias transformadas em produtos e mercadorias. Vivemos em um mundo de aparências, consumimos aparências e somos consumidos por elas.

A expressão de ordem das relações sociais mediadas pela dimensão espetacular da vida é: 'Apareço, logo existo'. [...] As instâncias sociais regidas pelo sistema espetacular são baseadas na contemplação passiva dos acontecimentos, em que os indivíduos, em vez de viverem autonomamente, olham avidamente as ações dos outros, por meio dos mais diversos dispositivos técnicos disponíveis (BITTENCOURT, 2011, p. 2).

A imediatez da imagem suscita e requer reflexos e reações também imediatos, e assim, exclui o movimento da reflexão, o que provoca uma transformação inaudita de despotencialização do pensamento. O esmagamento da duração da comunicação, do tempo para se falar, faz com que os indivíduos façam experiências que não tenham nenhuma relação com aquele de espaço-tempo da experiência humana, que exigem a vivência do tempo. O próprio conceito de alienação assim assume novos contornos, segundo Debord, nos termos da espetacularização da vida. Para o autor

[...] a alienação do espectador em proveito do objeto contemplado exprime-se assim: quanto mais se contempla, menos vive; quanto mais aceita reconhecer-se nas imagens dominantes da necessidade, menos ele compreende a sua própria existência e seu próprio desejo. [...] Os seus próprios gestos já não são seus, mas de um outro que lhes apresenta (DEBORD, 1997, p. 25).

Vivemos uma supremacia da economia sobre a vida e uma degradação do ser para o ter e do ter para o parecer - que pode ser traduzida no: "[...] apareço, logo existo [...]” (BITTENCOURT, 2011, p. 2). A mídia mercadológica, 
nestes termos, representaria a principal estrutura de defesa e manutenção da economia capitalista/consumista, pois instiga, por meio dos ditos apelos midiáticos, os indivíduos a correrem em busca da sua felicidade através do consumo de produtos, comportamentos e imagens que alegam conter em si a chave para a felicidade.

Ligando-se diretamente com o que diz Debord: “[...] o espetáculo é uma permanente guerra do ópio para confundir bem com mercadoria [...]" (1997, p. 44), a estrutura do capitalismo procura reproduzir-se por meio da alienação provocada nos indivíduos quando estes consomem de forma não mais consciente. Ou seja, a estratégia é a seguinte: os indivíduos consomem, pensam ou se comportam, sem ao menos saber o motivo ou o objetivo pelo qual consomem, pensam ou se comportam. É a característica básica da alienação.

A espetacularização da vida normal dos indivíduos contribui para a criação de uma imagem ideal da coisa a ser consumida, o que causará o desejo de possuir a referida coisa. E é isso o que move o sistema capitalista/consumista, de mercado. Debord (1997, p. 18) aponta que o espetáculo é "[...] nada mais que a economia desenvolvendo-se para si mesma. É o reflexo fiel da produção das coisas, e a objetivação infiel dos produtores”. O sistema capitalista apropria-se, assim, dessa espetacularização da vida real para desenvolver-se buscando fazer o indivíduo crer ser seus os bens produzidos pela sociedade capitalista, convertendo-se, desse modo, em defensor de sua manutenção. Ou seja, a Sociedade do Espetáculo é a própria sociedade capitalista, mas agora vista pelo uso de mecanismos de reprodução, como é o caso da mídia, procurando apresentar a sua forma mais sutil de estar presente na vida das pessoas, moldando-as por meio de mecanismos próprios.

Debord diz que a organização social, na atualidade, constitui-se como uma sociedade do espetáculo, pois não só tudo que era vivido se torna representação, mas a representação vem tornando-se o ideal que as pessoas querem viver. Além disso, percebe-se também a criação de estereótipos de heróis, de pessoas perfeitas, e estas representações imprimem nos indivíduos o desejo dos mesmos de se igualarem aos modelos. Nesse sentido, Fischer (2008, p. 23) aponta a mídia de caráter mercadológico como aquela que oferece o "[...] lugar da perfeição, em que desfilam pessoas e objetos inalcançáveis, em comparação com as vidas simples dos 'pobres mortais"'. Percebe-se que a imagem da perfeição que é apresentada faz com que se reafirme a tese que Debord usa para justificar a ideia do espetáculo: “[...] o que aparece é bom, o que é bom aparece” (DEBORD, 1997, p. 17).

Quando a realidade se converte em imagens, estas se tornam seres reais e motivam hipnoticamente os 
indivíduos a agirem de acordo com o espetáculo. Ou seja, a Sociedade do Espetáculo está viva e presente no meio social e precisa construir aparatos que venham torná-la invisível, dificultando, assim, a percepção de sua ação hipnótica, que é a de transformar pessoas em meros consumidores alienados de sua própria existência. Pode-se afirmar que, historicamente, a primeira fase da supremacia da economia sobre a vida social, que define toda pseudo (falsa) realização humana, é uma degradação do ser para o ter. Na Sociedade do Espetáculo, caracterizada como uma fase posterior à sociedade do ser para o ter, ocorre um deslocamento generalizado, da sociedade do ter para o parecer, como imagem, representação. Nela, “[...] o objeto material puro e simples dá lugar a uma multidão crescente de imagens-objetos, valorizada e consumida apenas como imagem [...]" (DEBORD, 1997, p. 15).

Somos constantemente bombardeados por imagens e apelos de consumo. Consumimos não só objetos, mas padrões de comportamento, maneiras de pensar, de nos relacionarmos e de viver, ao mesmo tempo em que, sem nos darmos conta, somos consumidos por eles. Assim, vê-se que o espetáculo, presente na realidade, é diretamente vivido pelas pessoas, de forma que estas não mais conseguem viver diretamente suas vidas, que se esvaem na fumaça da representação. Isto é possível pelo fato de as pessoas desejarem ter e ser coisas que na realidade são representações ideais da realidade, geradas pelo sistema econômico vigente. A mídia, de caráter mercadológico e comercial, costuma ser um instrumento do mercado e age em defesa do mesmo e na sua manutenção, instigando, para isso, os indivíduos a consumir e a tornar-se parte integrante dele. Seu funcionamento dá preferência à utilização de imagens que apresentam um estereótipo da perfeição, agregando ao imaginário do consumidor a necessidade de possuir determinado produto para que alcance um padrão ideal. Esta é uma das estratégias e formas que a mídia usa para suscitar nos indivíduos a necessidade de consumir.

Nesta configuração, de maneira geral, os meios de comunicação, em especial os veículos comerciais, se ocupam com o debate acerca dos temas de interesse público geralmente sob a lógica do capital e de forma incipiente mobilizam ações no campo das lutas democráticas de forma plural e dialógica. Uma realidade que provoca, instaura e consolida a exclusão, produz a subalternidade e que reduz ao silêncio os muitos discursos divergentes.

As mídias ditas hegemônicas, orientadas por um viés mercadológico, tendem a encarar os indivíduos, de forma geral, não como participantes efetivos e ativos de um diálogo, mas sim, como espectadores de um discurso de "mão única”, que mobiliza uma resposta previsível e orientada. 
Aos sujeitos, nessa lógica, caberia tão somente a ação de espectar, isto é, assistir, participar quase que de modo mecânico e reproduzir determinado discurso ou narrativa midiática, com algumas poucas exceções atuando na contracorrente. Seu papel resultaria reduzido a tão somente escolher entre receber as informações deste ou daquele veículo de comunicação.

O indivíduo é instigado a contemplar e consumir passivamente as imagens de tudo o que lhes falta em sua existência real. Isso cria dificuldade para que os mesmos ajam de forma autônoma ou sejam capazes de julgar e decidir conscientemente. Assim resume Bittencourt (2011, p. 3) este sistema:

[...] cada vez mais o sistema midiático da era tecnicista se caracteriza pela criação de gêneros de entretenimento de cunho majoritariamente alienante, servindo apenas para manter a consciência telespectadora preenchida do vazio intelectual e existencial de sua existência cotidiana. Isso ocorre pelo fato de que a disponibilização de programações de elevado refinamento cultural não é uma atividade muito conveniente para os propósitos meramente lucrativos das grandes redes de televisão, que preconizam, acima de tudo, manter a ordem medíocre vigente em nossa fragilizada cultura massificada. Trata-se de uma transposição contemporânea da política social do "Pão e Circo", que, em nossa contemporaneidade, se expressa em diversas configurações espetaculares, e uma delas se materializa no formato reality show. (BITTENCOURT, 2011, p. 3).

Desse modo, a realidade transforma-se em imagens, e as imagens tornam-se realidades. Repercute o argumento de Debord que contempla essa análise: "[...] no mundo invertido o verdadeiro é momento do falso [...]" (DEBORD, 1997, p. 16). Para Mattos (2005) a mercadoria é o totem capitalista ao qual o indivíduo se sacrifica. Isto é, a dúvida, a reflexão, a crítica, o diálogo encontram-se totalmente bloqueados.

Nesta perspectiva, a mídia de massa se consolida como um poder muito ligado ao modus operandi do mercado e à lógica da economia hegemônica, tornando-se meio de controle social e cultural e, sobretudo, um instrumento de poder.

Do ponto de vista do receptor, o aparelho de rádio e a televisão são eletrodomésticos como o liquidificador e a geladeira. Do ponto de vista do produtor, são centros de poder econômico (tanto porque são uma mercadoria 
que transmite e vende outras mercadorias) e centros de poder político ou de controle social ou cultural (CHAUÍ, 2006, p. 44).

Agindo desse modo: “[...] o rádio e a televisão podem oferecer-nos o mundo inteiro em um instante, mas o fazem de tal maneira que o mundo real desaparece, restando apenas retalhos fragmentados de uma realidade desprovida de raiz no espaço e no tempo" (CHAUÍ, 2006, p. 49-50), e podem esconder um processo opressor subjacente às entrelinhas da programação.

\section{A tarefa da educação numa sociedade do espetáculo}

A comunicação é um ato pedagógico, e a educação, um ato comunicativo. Neste sentido, a comunicação é elemento fundamental no processo de humanização do ser humano. É através dela que nos realizamos como pessoa e criamos um mundo que possibilite que isto aconteça na prática. Trata-se de um movimento de criação, de partilha, de sujeitos que falam e ao mesmo tempo se constituem nesse processo de comunicação. Recorremos ao educador Paulo Freire para compreendermos este movimento, para o qual os sujeitos se constituem na comunicação e é em torno dela e dos discursos que são produzidos nas interações humanas que se configuram os cenários sociais.

Mesmo que, ao falar de comunicação e sociedade, Freire ainda comumente se referisse aos meios de comunicação, se pode extrair de sua teoria do conhecimento ao longo de toda a sua obra e, mais precisamente em $\mathrm{Pe}$ dagogia do Oprimido (2017²) e Comunicação e Extensão $\left(1977^{3}\right)$, elementos que nos auxiliam a tecer reflexões acerca dos processos de comunicação e sociedade a fim de compreendermos a suas posições epistemológicas e suas contribuições para pensarmos os modos como se relacionam os indivíduos em uma sociedade que se fundamenta no espetáculo.

Sua crítica versava sobre a utilização da mídia não como meio de comunicação, mas quando se prestava e se reduzia à transmissão de informações e comunicados. Para Freire fenômeno comunicativo não se esgota em conceitos ou critérios como canais, meios, códigos, mensagens ou informações, mas se configura a partir do modo como os homens por meio da palavra instauram o mundo e a si mesmos. Ou seja, nos processos midiáticos se instauram cenários que extrapolam a discussão acerca dos meios, e que atingem o âmbito da comunicação e educação em práticas sociais.
2 O texto original foi escrito em 1970. Nós utilizaremos a $64^{\mathrm{a}}$ edição, publicada pela Paz e Terra em 2017.

3 O livro foi publicado em 1969 sob o título Extención o Comunicación?, pelo Instituto de Capacitación e Investigación en Reforma Agrária, em Santiago de Chile. Neste caso, utilizaremos $13^{\text {a }}$ edição, com tradução de Rosisca Darcy de Oliveira publicada em 1977 pela Paz e Terra. 
diz Paulo Freire, nós vivemos no mundo e com o mundo. E que mundo é esse? E aquele que é trazido até o horizonte de nossa percepção, até o universo de nosso conhecimento. Afinal, não podemos estar "vendo" todos os acontecimentos, em todos os lugares. É preciso que "alguém" os relate para nós. O mundo que nos é trazido, que conhecemos e a partir do qual refletimos, é um mundo que nos chega editado, ou seja, ele é redesenhado num trajeto que passa por centenas, às vezes milhares de filtros até que "apareça" no rádio, na televisão, no jornal. Ou na fala do vizinho e nas conversas dos alunos (BACCEGA, 1999, p. 177).

Segundo Paulo Freire (1977, p. 69), “[...] a educação é comunicação, é diálogo, na medida em que não é a transferência de saber, mas um encontro de sujeitos interlocutores que buscam a significação dos significados [...]”, num processo infinito que se constrói a partir da problematização-ação, alicerçada no diálogo crítico, libertador e na tomada de consciência como condição existencial de todo o homem. Portanto, a educação deve contribuir para que o homem se volte a buscar menos uma conformação ao mundo nos modos do espetáculo e mais uma atividade crítica e criadora do ser humano, para que saiam da posição de espectadores do processo histórico e assumam a atitude de cidadãos críticos e sujeitos de sua história.

A educação constrói-se no existir cotidiano. O ser-com-os-outros como modo de ser do homem é a possibilidade da liberdade, da justiça e da autonomia. No entanto, nem toda a prática educativa é humanizadora e emancipatória. Ao mesmo tempo, o lugar do público cotidiano na Sociedade do Espetáculo, onde tudo é para todos indistintamente, onde "[...] somos como os outros são", preocupamo-nos com o que 'a gente' se preocupa, pode também nos habituar ao 'afastamento' de nossas próprias responsabilidades e de nosso próprio ser e, tornar-se, o lugar do nivelamento ou 'uniformidade"' (CRITELLI, 1981, p. 65). O cotidiano do mundo público, onde se desenvolve a massificação e o espetáculo, encarrega-se de interpretar o mundo e o homem. O universo do "a gente", da imagem em forma de espetáculo, do discurso vazio, é também um educador, mas que despotencializa o pensamento.

Entendemos, a partir de Freire, que a comunicação social e a educação precisam contribuir para que os homens se constituam em sujeitos e partícipes do processo de construção de seus conhecimentos e significação de mundo.

A comunicação de massa e a educação convencional comumente tem caráter massificador, alienante, reprodutor do espetáculo que nos invade tendem a impedir a 
realização ontológica do humano que é ser sujeito. Na direção contrária, a educação, numa perspectiva contra hegemônica, pensada também por Freire, deve basear-se “[...] no respeito pelo outro, não visa acomodação ou ajustamento, mas enfatiza a integração que torna o homem sujeito de suas ações e o afasta da condição de objeto, de dominado, sem vez e sem voz" (DELIBERADOR; LOPES, 2012, p. 12).

Freire, no texto “Extensão ou Comunicação?” (1977), elabora uma consistente crítica ao extensionismo e ao que ele chama de pedagogia da domesticação, contrapondo a educação bancária com os processos de educação e comunicação de caráter problematizador. Os processos educativos e comunicativos precisam estar fundamentados numa epistemologia marcada pelo respeito aos saberes cotidianos, da existência humana, "[...] tratando de descobrir a teoria presente na prática popular, teoria ainda não conhecida pelo povo, problematizando-a também, incorporando-lhe um raciocínio mais rigoroso, científico e unitário" (GADOTTI, 2012, p. 7).

As críticas de Debord (1997) se dão sobre quaisquer possibilidades que possam levar o homem à aceitação dos valores preestabelecidos pelo capitalismo desumano. Com isso, tem por objetivo suscitar uma reflexão acerca da manipulação cultural e social a que estariam submetidos os indivíduos, instigando-os a agir contra qualquer tipo de opressão. A teoria crítica da sociedade proposta pela Escola de Frankfurt é ainda muito pertinente, pois fomenta a reflexão a fim de descortinar uma realidade reificada e contaminada por uma lógica mercadológica que desumaniza. Para isso, é necessário diagnosticar e revelar as artimanhas desse tipo de sociedade para que a própria vida não caia numa artificialidade irrecuperável devido à nossa apatia e ao nosso sono em relação a essa problemática. Dessa forma, diz Debord: "[...] o espetáculo é o mau sonho da sociedade moderna acorrentada, que ao cabo não exprime senão o seu desejo de dormir. O espetáculo é o guardião desse sono" (DEBORD, 1997, p. 20). É preciso recuperar as potencialidades da reflexão crítica e o diálogo emancipador que permitam analisar, interpretar e propor caminhos que nos levem a resgatar a vida humana desgastada pela superficialidade e pela economia da sociedade de consumo.

Nesse sentido, Freire nos exorta a pensarmos uma educação que seja libertadora, pensada e fundamentada na compreensão de que o homem é sempre possibilidade que se abre temporalmente e se pergunta pelos sentidos a partir do mundo que o circunda dando-lhe inteligibilidade de forma consciente e crítica. A educação como prática da liberdade, não é a transferência ou a transmissão do saber, nem da cultura, (como faz a mídia mercadológica de massa e as estruturas que mantêm processos educacionais 
convencionais); "[...] não é a extensão de conhecimentos técnicos; não é o ato de depositar informes ou fatos nos educandos; não é a perpetuação dos valores de uma cultura dada; não é o esforço de adaptação do educando a seu meio [...]” (FREIRE, 1977, p. 78). A educação libertadora não pode ser uma narrativa verbalista ou se constituir numa espécie de assistencialismo educativo, no qual alguém (professor, escola, igreja, meio de comunicação de massa, etc) se limita a dissertar, narrar ou apenas falar de algo. Nesta perspectiva, o homem é anestesiado e transformado em depósito de informes, imagens e consumidor de produtos e ideias bem embaladas. O que fundamentalmente importa à educação é o diálogo problematizador que se dá em torno de situações reais, num retorno crítico à ação, num processo de tomada de consciência que solidariza os indivíduos como sujeitos cognoscentes. Processo este mediado pelo objeto cognoscível, pelo mundo e pela vida em que ambos constroem e reconstroem permanentemente, enquanto agem e trabalham, o sentido de seus saberes e do viver, que se opera no encontro e no diálogo, tornando-se sujeitos de seu próprio processo de conhecimento. "A tarefa do educador, então, é a de problematizar aos educandos o conteúdo que os mediatiza, e não a de dissertar sobre ele, de dá-lo de estendê-lo, de entregá-lo, como se tratasse de algo já feito, elaborado, acabado, terminado" (FREIRE, 1977, p. 81).

Para isso, a educação deve estimular o ímpeto criador do ser humano, como forma de combater a acomodação ao mundo. Um dos preceitos fundamentais para a compreensão das práticas educativas dotadas de uma finalidade libertadora e emancipatória consiste em considerar o educando como ser inacabado, que por meio da consciência de seu inacabamento encontra na Educação um processo permanente de busca (DELIBERADOR; LOPES, 2012, p. 10).

Os sistemas educativos e midiáticos que se orientam sob a égide da transmissão e reprodução de padrões de comportamento, maneiras de pensar, de consumir e as práticas pedagógicas que se baseiam nela se desenvolvem em meio a um formalismo oco, constituindo-se em uma espécie de "[...] assistencialismo educativo [...]" (FREIRE, 1977, p. 80). O narrador, obedecendo às ordens advindas de um sistema econômico que procura apenas a sua manutenção e proliferação, nesta perspectiva, esforça-se em entregar um produto, no caso um conhecimento, um saber, um modo de pensar, uma informação como se tratasse de algo já feito, pronto, elaborado, acabado, terminado. Este, do ponto de vista de Freire, é o grave equívoco gnosiológico da extensão e de uma sociedade alimentada pelo capital e 
fundamentada no Espetáculo : “[...] o conteúdo estendido se torna estático [...]" (FREIRE, 1977, p. 26). O esforço do assistido, do ouvinte, por sua vez, estaria concentrado em guardar, consumir e reproduzir passivamente aquilo que recebe. Este movimento unilateral, de um emissor que fala e transmite e um receptor que escuta e reproduz o que recebe da forma como recebe, e que considera os sujeitos sociais e pedagógicos como fixos, essenciais ou inflexíveis, para Freire, tende a gerar um efeito anestésico nos envolvidos no processo. Em tal narrativa verbalista, tanto receptor, na condição de assistido ou assistente, quanto emissor, dissertador de um saber, distanciam-se e alienam-se de suas práticas cotidianas e históricas e a elas não voltam suas reflexões e esforços a fim de compreendê-las de forma esclarecida e crítica.

Ademais, práticas assistencialistas implicam, no fundo, em obstáculos à transformação, ou seja, constituem-se em instrumento de dominação, frustrando as expectativas de que os dominados se reconheçam como dominados e tomem consciência da condição em que se encontram. De fato, material e intelectualmente, tal concepção que rejeita a educação como uma situação gnosiológica "[...] é rígida, dogmática e autoritária [...], para dominar, o dominador não tem outro caminho senão negar às massas populares o direito de dizer sua palavra [...]" (FREIRE, 2017, p. 170).

Freire ressalta, por inúmeras vezes, que a ação antidialógica da qual se servem os invasores para lograrem seus objetivos e persuadir os invadidos, não se faz pela comunicação, mas centra-se em propagandas, slogans, representações e comunicados, significados que se esgotam em seu dinamismo transformando-se em conteúdos estáticos, cristalizados. A crítica dirigida aos que se valem dos veículos chamados por ele de "[...] meios de comunicação com as massas [...]" (FREIRE, 2017, p. 189), ou "[...] meios de comunicados às massas [...]" (FREIRE, 1977, p. 72) consiste na crença inabalável de que a inteligibilidade do mundo é uma doação, uma concessão, levada às massas por propagandas e imagens bem organizadas, bem embaladas, técnicas de propaganda e de persuasão e slogans que obedecem uma verticalidade aparentemente inquebrantável de emissor-receptor. Uma pedagogia dos depósitos, "como se o depósito deste conteúdo nelas (nas massas) fosse realmente comunicação" (FREIRE, 2017, p. 189). Para Freire, os meios de comunicação de massa, como símbolos mais visíveis deste tipo de sociedade, tendem ao extensionismo quando reduzem sua ação a um ato de transmissão ou de extensão sistemática de um saber.

Se um sujeito é transformado em paciente de comunicados não há comunicação. "É indispensável ao ato comunicativo, o acordo entre sujeitos, reciprocamente 
comunicantes. A expressão verbal dos sujeitos tem de ser percebida [...]" (FREIRE, 1977, p. 67), ouvida, respeitada, considerada no encontro em que sujeitos buscam a significação dos significados e não silenciada, aviltada, dirigida ou ignorada. No processo de extensão, "[...] o máximo que se pode fazer é 'mostrar', [...] aos indivíduos, uma presença nova: a presença dos conteúdos estendidos" (FREIRE, 1977, p. 28).

A estrutura da ação antidialógica marcada pela extensão como um fazer em que está implícita a "[...] ação de levar, de transferir, de entregar, de depositar algo em alguém [...]" o que ressalta uma conotação visivelmente mecanicista e que contribui para a manutenção de uma sociedade fundamentada na representação do real como espetáculo e onde as relações humanas são mediadas por imagens (FREIRE, 1977, p. 26).

A ação que Freire chama antidialógica assenta-se, segundo o autor, em alguns elementos, a saber: conquista, dividir para manter a opressão, manipulação e invasão cultural.

O primeiro caráter é a necessidade da conquista: massas conquistadas, massas espectadoras, seriam para ele, passivas. Esta conquista poderia se dar de muitas formas, "[...] desde as mais repressivas às mais adocicadas como o paternalismo [...]” (FREIRE, 2017, p. 186). Para ele uma situação de opressão se perpetua quando o opressor propõe às massas um conjunto de verdades e mitos como algo dado ao qual todos devem se ajustar. Os meios de comunicação, que invariavelmente estão sob o controle das classes dominantes, tenderiam a reforçar esta sloganização ao se tornarem instrumentos de propagação deste "[...] mundo de engodos [...]" (FREIRE, 2017, p. 187). O segundo caráter da ação antidialógica diz respeito à mecânica de dividir as massas para enfraquecê-las e assim manter a opressão. Conceitos de "[...] união, organização, de luta, são timbrados, sem demora, como perigosos [...]" (FREIRE, 2017, p. 190) e, portanto, não incentivados e até reprimidos, ou por uma maquinaria burocrática estatal, ou por ações culturais, midiáticas e processos educativos por meio das quais as massas são manejadas. Aqui há uma conotação messiânica através da qual os dominadores se apresentam como salvadores dos homens a quem desumanizam. Diz Freire (2017, p. 196), “[...] o que eles querem é salvar-se a si mesmos (manter o status quo). É salvar sua riqueza, seu poder, seu estilo de vida, com que esmagam os demais". Uma terceira característica da ação antidialógica é a manipulação. Através de táticas de manejo, inclusive com a utilização dos meios de comunicação de massa, as elites dominadoras distraem as massas, fazem com que os dominados aceitem sua palavra, sua versão sobre a realidade 
de tal forma a "[...] anestesiar as massas populares para que não pensem" (FREIRE, 2017, p. 2000) e inoculando no oprimido o sonho do êxito pessoal do burguês. Por fim, aqueles que propagam a ideia de que são "superiores" penetram no universo cultural dos considerados "inferiores" impondo a estes sua visão de mundo, de tal forma que o invadido adere ao invasor a ponto de querer "[...] parecer com aqueles: andar como aqueles, vestir à sua maneira, falar a seu modo" (FREIRE, 2017, p. 207). As próprias instituições (família, escola, meios de comunicação) acabam funcionando como agências formadoras de futuros "invasores" e reafirmando o fato de que apenas alguns têm o privilégio ou capacidade de ter visão de mundo e expressá-la aos outros ${ }^{4}$.

Paulo Freire adota uma postura política muito clara em defesa de um processo educativo-comunicativo que gere transformação social, e que propicie ambiente favorável à formação do sujeito autônomo, capaz de pensar criticamente, compreender de forma radical a sociedade em que está inserido para assim atuar de maneira responsável e consciente e não somente memorizar e repetir, consumir passivamente. Para ele um processo educativo que alcance tal intento só é possível na medida em que se reconheça a educação e a comunicação como situações gnosiológicas, fundamentadas numa relação marcada pelo respeito e consideração aos saberes do outro e em torno de situações reais, concretas e existenciais. Ao propor o rompimento dos fluxos unilaterais de comunicação, a interação (emissor-receptor) tende a se converter em uma situação epistêmica, abrindo caminhos para um pensar problematizador, que se dá a partir do diálogo comunicativo. Somente na comunicação e não na extensão tem sentido a vida humana. Interação não se dá por um emissor que fala e um receptor que escuta, mas significa encontro entre sujeitos que compartilham experiências, de forma presencial, ou mesmo hoje, ainda que seja à distância, através de meios artificiais e mediados pelo objeto de conhecimento, ressignificado constantemente.

O autor propunha desta forma a necessidade de se pensar epistemologicamente, quer dizer, considerar a matriz dialogal como ancoragem normativa para o processo de comunicação, seja ela mediada tecnologicamente ou não. No entanto, falar, por exemplo, em democracia e silenciar o povo é uma farsa. Falar em humanismo e negar os homens é uma mentira. Precisamos estabelecer entre os homens um diálogo a partir de uma linguagem que favoreça, não somente no nível do discurso, mas igualmente na prática humana, atitudes problematizadoras e humanistas em contraposição às correntes dominadoras, que tiram do homem sua liberdade e esperança.

\begin{abstract}
4 Freire dedica uma nota de rodapé em Extensão ou Comunicação? (FREIRE, 1977 , p. 80-81) para indicar que mesmo nestas condições a esperança se mantém viva, ao afirmar que a condição de "assistidos" dos indivíduos não é eterna ou imutável e cita os movimentos sociais e populares, especialmente os considerados rebeldes encabeçados pela juventude como questionadores deste modelo e que colocam em cheque a validade dos "comunicados feitos assistencialisticamente", além de exigirem uma educação que vá além do conhecimento do como, mas que preocupe-se com o quê, o porquê e o para quê das coisas, da ação e da existência.
\end{abstract}




\section{Considerações finais}

Freire destaca que o esforço exigido no processo de problematização deriva de uma decisão, de uma opção político-pedagógica dos sujeitos, ou seja, não é oriundo de uma iluminação ou de qualquer forma de doação ou concessão, e não se configura como um entretenimento intelectualista ou uma fuga da ação. Ao contrário, revela-se como um compromisso com a reflexão e com a ação, pois é inseparável tanto do ato cognoscente quanto das situações humanas concretas. Parte da ação e a ela retorna com um olhar crítico capaz de transformá-la. Não se pode falar em problematização e comunicação sem a presença umbilical da realidade vivida, do mundo da cultura, da história, enfim, daquilo que resulta das relações homem-mundo e que condiciona seus próprios criadores, os homens.

No entanto, a atitude problematizadora em torno do homem-mundo, além de exigir um compromisso político, uma opção pela transformação social e um engajamento sócio-histórico pressupõe uma postura de humildade. Uma atitude humilde não significa subserviência ou passividade aos apelos da Sociedade do Espetáculo, mas pressupõe fundamentalmente o reconhecimento da ignorância e o respeito aos saberes e vozes dos outros, e, mais que isso, implica num posicionamento de abertura ao diferente, ao diálogo, uma ativa e reflexiva posição de re-admirar-se constantemente a partir daquilo que é problematizado. Os sujeitos, nesta perspectiva, estariam sempre aprendendo, e sempre haverá algo a aprender e a significar.

Para cumprir estes objetivos, todo processo que se quer educativo e libertador deveria, para Freire (1977), dar lugar à manifestação interativa dos sujeitos que ora convertem-se em educandos e, ao mesmo tempo, educadores, em lugar de confiná-los a um mero papel de espectadores, receptores, ouvintes ou mesmo consumidores. Neste sentido, segundo o autor, se a educação configura-se como uma relação entre sujeitos cognoscente, mediados pelo objeto cognoscível, necessariamente ela é um "[...] que fazer problematizador" (FREIRE, 1977, p. 81), onde ambos reconstroem e ressignificam igual e permanentemente seus saberes e como sujeitos no mundo permanentemente, na interação face aos sentidos daquilo que foi problematizado. Mudança de postura, de uma "cultura do silêncio" das maiorias, ou de uma cultura da submissão, do cidadão ausente, alienado, preso às imposições do espetáculo, de um cidadão sem voz, para uma cidadania ativa, participativa e dialogada. Tal processo potencializaria a criação de condições favoráveis para que estes sujeitos gerem suas próprias mensagens, de forma autônoma, não individual, mas coletivamente, a fim de que possam apresentar, por sua vez, outras formas de significar o mundo acerca do qual e no qual nos comunicamos. 
Por fim, partindo do pressuposto de que os indivíduos estabelecem uma relação quase que ubíqua com as tecnologias da informação e comunicação, e, por extensão, com as diversas mídias, as adicionando de modo quantitativo e qualitativo ao seu universo pessoal e social, faz-se imprescindível pensar que tipo de relação estabelecemos com elas, bem como pensarmos na formação do indivíduo que com elas convive hodiernamente. Cresce, cada vez mais, na sociedade da informação, a necessidade e urgência de estabelecermos processos pedagógicos (formais ou informais) que capacitem os sujeitos a fim de que sejam capazes de, aproveitando os recursos e as oportunidades que os meios e as redes de comunicação oferecem, efetivamente, estabelecerem uma relação ativa, autônoma, crítica e responsável para e com eles.

Na denominada Sociedade do Espetáculo, diagnosticada por Debord (1997), em que reinam as modernas condições de produção econômicas, a vida se apresenta como uma imensa acumulação de espetáculos. Freire sugere a adoção de processos educativos-comunicativos alicerçados na colaboração e no diálogo com vistas à formação de um sujeito autônomo e transformação social. Esta postura colaborativa desencadeia uma aproximação entre os oprimidos que compartilham de situações concretas semelhantes. "Para que os oprimidos se unam entre si é preciso que cortem o cordão umbilical, de caráter mágico e mítico, através do qual se encontram ligados ao mundo da opressão" (FREIRE, 2017, p. 239). Sujeitos se encontram para pronunciar o mundo, sem que haja imposições invasivas, manejo, domesticação ou sloganização. Pronunciar o mundo é um aprendizado e não é possível que se faça com autoritarismo, nem com licenciosidade, mas é um momento "[...] altamente pedagógico em que a liderança e o povo fazem juntos" (FREIRE, 2017, p. 245).

Uma ação cultural dialógica pressupõe a superação de qualquer ação dirigida, induzida ou impositiva. Isso, por outro lado, não implica a supressão de toda e qualquer diferença em termos de autoridade e nível de consciência dos envolvidos. Mas é uma ação em que não se entrega nada, não há espectadores, não há modelos impostos, não se nega as diferentes visões de mundo, os sujeitos co-participam no ato de compreender a significação dos significados, a fim de que a vida não caia numa artificialidade irrecuperável devido à nossa apatia em relação à lógica da economia hegemônica, rígida, dogmática e autoritária.

\section{Referências}

ARBAX JUNIOR, José. Showrnalismo: a notícia como espetáculo. 2001. Tese (Doutorado) - Curso de Doutorado em História, Universidade de São Paulo, São Paulo, 2001. 
BACCEGA, Maria Aparecida.Comunicação \& Educação: do mundo editado à construção do mundo. Comunicação \& Informação, [S.l.], v. 2, n. 2, p. 176- 187, 1999.

BITTENCOURT, Renato Nunes. Apareço, logo existo. Revista Filosofia e Ciência, n. 57. 2011.

CHAUÍ, Marilena. Simulacro e poder: uma análise da mídia. Editora Fundação Perseu Abramo, 2006.

CRITELLI, Dulce Maria. Todos nós ... ninguém: um enfoque fenomenológico do social. São Paulo: Moraes, 1981.

DEBORD, Guy. A sociedade do espetáculo. Rio de Janeiro: Contraponto, 1997.

DELIBERADOR, Luzia Yamashit; .LOPES, Mariana Ferreira.O legado de Paulo Freire para a pxáxis de midiaeducação na perspectiva da comunicação comunitária. In.: Anais. XVI Colóquio Internacional da Escola Latino-Americana de Comunicação. Bauru - São Paulo. 8 a 10 de agosto 2012. Disponível em: http://www2.faac.unesp.br/ celacom/anais. Acessado em: 20 jul. 2020.

FREIRE FILHO, João. A sociedade do espetáculo revisitada. Revista Famecos, v. 10, n. 22, p.33-46, dez. 2003.

FISCHER, Rosa Maria Bueno. Mídia, juventude e educação: modos de construir o "outro" na cultura. Arquivos Analíticos de Políticas Educativas, v. 16, n. 2, p.1-20, jan. 2008.

FREIRE, Paulo. Extensão ou comunicação? tradução de Rosisca Darcy de Oliveira. 7.ed. Rio de Janeiro, Paz e Terra, 1977.

FREIRE, Paulo; GUIMARÃES, Sérgio. Educar com a mídia: Novos diálogos sobre educação. 3. ed. São Paulo: Paz e Terra, 2011.

FREIRE, Paulo. Pedagogia do oprimido. 64 ed. Rio de Janeiro/São Paulo: Paz e Terra, 2017.

GADOTTI, Moacir. Educação Popular, educação social, educação comunitária: conceitos e práticas diversas, cimentadas por uma causa comum. In.: Anais. 4 Congresso Internacional de Pedagogia Social e Congresso Internacional de Pedagogia Social, 2012, São Paulo, SP, Brasil [online]. Disponível em: www.proceedings.scielo.br/pdf/cips/ n4v2/13.pdf. Acessado em 28 jul. 2020.

MATTOS, Olgária Chain Féres. O sex appeal da imagem e a insurreição do desejo. 2005. Disponível em: https://ar- 
tepensamento.com.br/item/o-sex-appeal-da-imagem-e-a-insurreicao-do-desejo/. Acesso em: 05 jul. 2020.

Enviado em: 13-09-2019

Aceito em: 29-06-2020

Publicado em: 05-08-2020 